Cornell Law Library

Scholarship@Cornell Law: A Digital Repository

Cornell Law Faculty Publications

Faculty Scholarship

$1-1-1989$

\title{
The Vienna Sales Convention 1980 and the Hague Uniform Laws on International Sale of Goods 1964: A Comparative Analysis
}

Muna Ndulo

Cornell Law School, mbn5@cornell.edu

Follow this and additional works at: http://scholarship.law.cornell.edu/facpub

Part of the International Trade Commons

\section{Recommended Citation}

Ndulo, Muna, "The Vienna Sales Convention 1980 and the Hague Uniform Laws on International Sale of Goods 1964: A Comparative Analysis" (1989). Cornell Law Faculty Publications. Paper 66.

http://scholarship.law.cornell.edu/facpub/66

This Article is brought to you for free and open access by the Faculty Scholarship at Scholarship@Cornell Law: A Digital Repository. It has been accepted for inclusion in Cornell Law Faculty Publications by an authorized administrator of Scholarship@Cornell Law: A Digital Repository. For more information, please contact jmp8@cornell.edu. 


\title{
THE VIENNA SALES CONVENTION 1980 AND THE HAGUE UNIFORM LAWS ON INTERNATIONAL SALE OF GOODS 1964: A COMPARATIVE ANALYSIS
}

\author{
Muna Ndulo*
}

\section{INTRODUCTION}

THIS article compares the provisions of the UN Convention on Contracts for the International Sale of Goods (Vienna, 1980- "the UN Sales Convention") ${ }^{1}$ to those of the Uniform Law on the International Sale of Goods (ULIS) and the Uniform Law on the Formation of Contracts of Sale (ULF) (Hague Conventions, 1964). ${ }^{2}$ The ULIS and the ULF served as the underlying documents for the elaboration of the 1980 UN Sales Convention. Both the ULIS and the ULF did not fulfil the expectations which their signing in 1964 had ushered in. The number of States which have ratified the two Conventions has remained small. The UN Sales Convention has received the required number of ratifications or accessions and came into force on 1 January 1988. It is expected to be adhered to by many more States in the near future and will become the law applicable to the majority of all contracts for the international sale of goods. ${ }^{3}$

* LL.B. (Zambia), LL.M. (Harvard), D. Phil (Oxford), Legal Officer, International Trade Law Branch, Office of Legal Affairs, United Nations, Professor of Law, University of Zambia (on leave). The views expressed herein are those of the author and do not necessarily reflect the views of the United Nations.

1. Final Act of the UN Conference on Contracts for the International Sale of Goods (A/CONF.97/18), Yearbook (1980) part 3, Chap.I. Section A (reproduced in Official Records of the UN Conference on Contracts for the International Sale of Goods, UN publication No.81.IV.3, Part 1). There are several unofficial sources for the text of the Convention, e.g. (1980) 19 I.L.M. 668-669; J. Honnold, Uniform Law of International Sales under the 1980 United Nations Convention (1982), pp.469-503.

2. The text of the ULIS may be found in the Convention Relating to a Uniform Law on the International Sale of Goods, ULIS, p.107 reprinted in (1964) 3 I.L.M. 855, and of the ULF may be found in the Convention Relating to a Uniform Law on the Formation of Contracts for the International Sale of Goods, 834 U.N.T.S. 169, reprinted in (1964), 3 I.L.M. 864.

3. Already the list includes Argentina, China, Egypt, France, Hungary, Italy, Syria, Lesotho, Zambia, Austria, Finland, Mexico, Norway, Sweden, US, Yugoslavia and Australia. 


\section{ORIGINS OF THE 1964 HAGUE CONVENTIONS AND THE 1980 UN SALES CONVENTION}

\section{A. History}

The efforts to achieve a uniform law for international sales have a long history. ${ }^{4}$ The UN Sales Convention is the outcome of a long process of unification whose origin goes back to the early days of the movement in respect of the unification of international trade law. In April 1930 the International Institute for the Unification of Private Law (UNIDROIT) decided to undertake the preparation of a uniform law on the international sale of goods. Drafts were prepared and submitted for comments to governments through the League of Nations prior to the cessation of work on this project in 1939 due to the Second World War. In 1951 the government of the Netherlands organised a diplomatic conference on the international sale of goods in order to consider the draft prepared by UNIDROIT and to determine the means by which the work could be brought to a successful conclusion. The conference decided that the work should be continued and appointed a special committee to prepare a new draft on the basis of the suggestions made at the conference. The special committee prepared a revised draft in 1956, which was circulated by the government of the Netherlands to interested governments for comments. On the basis of replies a modified draft was prepared by the special committee in 1963. In 1964 the government of the Netherlands convened a diplomatic conference at The Hague to which it submitted the 1963 draft for consideration.

In the meantime UNIDROIT had prepared a draft of the ULIS and the ULF. The government of the Netherlands also circulated this draft to interested governments for their comments. The draft and the comments thereon were also submitted to the 1964 Hague conference, which adopted the two Uniform Laws as well as the Conventions to which they were annexed, i.e. the Convention relating to a Uniform Law on the International Sale of Goods ("1964 Hague Sales Convention") and the Convention relating to a Uniform Law on the Formation of Contracts for the International Sale of Goods ("1964 Hague Formation of Contracts Convention"). The two 1964 Hague Conventions were opened for signature on 1 July 1964. The 1964 Hague Sales Convention entered into force on 18 August 1972. It has been ratified, or acceded to, by Belgium, Gambia, the Federal Republic of Germany, Israel, Italy, the Netherlands, San Marino, and the United Kingdom. The Hague

4. See historical introduction to the draft Convention on Contracts for the International Sale of Goods, prepared by the Secretariat (reproduced in Official Records of the United Nations Conference on Contracts for the International Sale of Goods, Part 1, Section B) (originally published as the introduction to document A/CONF. 97/5). 
Formation of Contracts Convention entered into force on 23 August 1972. It has been ratified, or acceded to, by the States listed above, with the exception of Israel.

In 1966 the UN General Assembly created the United Nations Commission on International Trade Law (UNCITRAL). ${ }^{5}$ The Commission was entrusted with the duty of furthering the progressive harmonisation and unification of the law of international trade by, among other ways, preparing or promoting the adoption of new international conventions, model laws and uniform laws and promoting the codification and wider acceptance of international trade terms, provisions, customs and practices. $^{6}$

At the first session of UNCITRAL, held in 1968, it was decided that in respect of the two 1964 Hague Conventions, which were then not yet in force, the Commission should determine the position of States in respect of those Conventions. Accordingly, the Commission requested the Secretary-General to send a questionnaire to member States of the UN and member States of any of its specialised agencies. ${ }^{7}$ The replies and an analysis of the replies were submitted to the second session of the Commission in $1969 .{ }^{8}$ After consideration of the replies, the Commission decided to create a working group on the international sale of goods, consisting of 14 member States, which was instructed to ascertain "which modifications of the existing texts might render them capable of wider acceptance by countries of different legal, social and economic systems, or whether it will be necessary to elaborate a new text for the same purpose". ${ }^{9}$ The working group in both cases recommended the adoption of new texts. An analysis of the answers revealed that the existing texts of the ULIS and the ULF were unlikely to command such wider acceptance by many countries. Among the objections raised were the following.

1. The Hague Conference, at which the Conventions were adopted, had been attended by only 28 States and the socialist and the developing countries had not been adequately repre-

5. G.A. Res. 2205 (XXI), Yearbook (1968-1970), Part 1, Chap.II, Section E.

6. See generally G.A.Res. 37/106, para.7, Yearbook (1982), Part 1, Section D) and specifically G.A. Res.2205 (XXI), Section II, para.8, Yearbook (1968-1970), ibid.

7. G.A. Official Records, 23rd Session, Supp.16 (A/7216).

8. "Replies and studies by States concerning the Hague Conventions of 1964: note by the Secretary-General" (A/CN.9/11 and Corr. 1 and add. 4). See also the analysis of these replies and studies prepared by the Secretariat: 'International Sale of Goods: The Hague Conventions of 1964: Analysis of the replies and studies received from governments: report of the Secretary-General" (A/CN.9/17); "Analysis of the studies and comments by Governments on the Hague Conventions of 1964: report of the Secretary-General" (A/ CN.9/3).

9. Official Records of the UN Conference on Contracts for the International Sale of Goods (A/CONF.97/19). 
sented. ${ }^{10}$ This seemed to encourage a belief that the Hague Conventions favoured the sellers of manufactured goods in the industrialised nations. In any case, without the adequate participation of the developing countries and socialist countries, the hope that the Hague Conventions would become internationally accepted could not be fulfiled.

2. The ULIS used abstract and complex concepts which could easily result in ambiguity and error and could not be easily understood by businessmen.

3. The ULIS pointed more to external trade between common boundary nations geographically near to each other, and insufficient attention had been given to international trade problems involving overseas shipments.

4. The scope of application was considered by many as too broad as it was to apply regardless of conflict rules. ${ }^{11}$

At its tenth session in 1977, UNCITRAL adopted the draft Convention on the International Sale of Goods ${ }^{12}$ based on the text submitted by the working group, and in 1978 at its 11 th session adopted the Rules on the Formation of Contracts for the International Sale of Goods, also based upon the text proposed by the working group. UNCITRAL also decided to combine the draft Convention it had adopted at its tenth session and the Rules into a single instrument-the draft Convention on Contracts for the International Sale of Goods. This draft formed the basis of the UN Sales Convention. ${ }^{13}$

\section{SPHERE OF APPLICATION}

\section{A. Scope}

The Uniform Laws and the UN Sales Convention are both concerned primarily with the general principles of the law of sales. The special terms of the contract remain to be defined by the parties to the contract themselves. This approach is sound. It is in the realm of general principles that certainty and universality are needed. Any attempt at defin-

10. Ibid., only Egypt and Yugoslavia participated from the Third World.

11. See H. J. Berman, "The Uniform Law on International Sale of Goods: A Constructive Critique" (1966) 30 Law and Contemp. Probs. 354.

12. G.A. Official Records, 32nd Session, Supp.17 (A/32/17). The draft was published with a commentary prepared by the UNCITRAL Secretariat. It is the subject of several articles in a symposium on the work of UNCITRAL published in (1979) 27 A.J.C.L. 243.

13. The conference also adopted a protocol amending the Convention of the Limitation Period in the International Sale of Goods (New York, 1974) in order to harmonise the provisions of that Convention in respect of the sphere of application, with those of the UN Sales Convention. G.A. Official records, 33rd Session, Supp.17 (A/33/17). Final Act of the UN Conference on Contracts for the International Sale of Goods (A/CONF.97/18). The Convention is set forth in Annex I of the Final Act. 
ing special terms is to disregard practice and the differences which exist in the practice of the many different types of trade. Both the ULIS and the UN Sales Convention have similar provisions regarding scope. ${ }^{14}$ The most important principle is that the texts cover only the relationship between the buyer and the seller. They do not regulate the rights of third parties. The texts do not cover the passing of property (transfer of ownership) and consequently are not concerned with the rights of a third party who acquires the property or of creditors of a buyer or seller in the event of bankruptcy: all such matters are left to be governed by national law.

It is expressly stated by the UN Sales Convention ${ }^{15}$ and the ULIS ${ }^{16}$ that, except as otherwise expressly provided in the Convention, the validity of the contract is not covered. Examples of matters which are thus outside the scope of the Uniform Laws are: capacity of the parties; exchange control legislation; price control legislation; legislation requiring export licences for certain goods; rules concerning contracts contra bonos mores; rules regarding contracts against public policy; legislation intended to protect the weaker party; and questions of fraud, duress and mistake. The Convention in addition does not govern product liability. ${ }^{17}$ This was understood to be the interpretation in the ULIS as well but it was not a written rule. ${ }^{18}$

\section{B. Consumer Contracts, Auctions, Stocks and Securities Excepted}

The UN Sales Convention and the ULIS exclude certain types of sales from the ambit of the Conventions. ${ }^{19}$ They both exclude consumer sales. This is because in a number of countries consumer sales are subject to various types of national laws designed to protect consumers. Exclusion avoids any risk of impairing the effectiveness of such national laws. But there is a significant difference between the two Conventions. Article 2(a) of the UN Sales Convention states that the Convention does not apply to sales of goods bought for personal, family or household use, unless the seller, at any time before or at the conclusion of the contract, neither knew nor ought to have known that the goods were bought for any such use. The equivalent provision in the ULIS (Article 5(2)) states that the ULIS shall not affect the application of any mandatory

14. UN Sales Convention, Art.4, and ULIS, Art.8; see also ULF, Art.1.

15. UN Sales Convention, Art.4(a).

16. ULIS, Art.8.

17. UN Sales Convention, Art.5.

18. See T. C. Hartley, The Law Relating to International Sale of Goods, A Study of the Uniform Law on International Sale of Goods. Including the Uniform Law on the Formation of Contracts for the International Sale of Goods (The Hague Conventions 1964) and the Draft Convention on Contracts for the International Sale of Goods prepared by the United Nations Commission on International Trade Law (1979), p.2-7.

19. See UN Sales Convention, Art.2(a), and ULIS, Art.5. 
provision of national law for the protection of a party to a contract which contemplates the purchase of goods by that party by payment of the price by instalments. This differs in two important ways from the UN Sales Convention text. First, it does not exclude such contracts from the scope of the ULIS; it merely allows national mandatory provisions for the protection of the buyer to override the ULIS. Secondly, it identifies consumer transactions with instalment sales. This could cause some misunderstandings, in that many commercial sales provide for the payment to be made in instalments, especially in the case of expensive items of equipment, and much similar legislation applies even where the price is paid in a single instalment.

\section{Uniform Character with Regard to the Civil or Commercial Character of the Legal Relationship}

The Uniform Laws and the Convention apply irrespective of the civil or commercial character of the parties or the contract. ${ }^{20}$ This is stated in Article 1(3) of the UN Sales Convention, and the ULIS equivalent is also Article 1(3). Contracts for the supply of goods to be manufactured or produced are regarded as sales for the purpose of both Conventions. The relevant articles are Article 3(1) for the UN Sales Convention and Article 1(7) of the ULF. However, where the party ordering the goods undertakes to supply the materials, such a contract will not be covered by the UN Sales Convention (Article 3(1)) if he supplies a substantial part of the materials. Under the ULF rules, the contract will not be covered if he undertakes to supply an essential and substantial part of the materials. Contracts of sales and services where the preponderant part of the sellers' obligations consists in the supply of labour or other services are excluded by the UN Sales Convention in Article 3(2). The ULF leaves the exclusion of this type of contract to implication. Both Conventions, however, exclude sales on execution or otherwise by authority of law. Sales of stocks, shares, investment securities, negotiable instruments or money, sales of ships, aircraft or vessels and sales of electricity are also excluded. ${ }^{21}$ The reason for the exclusions is that sales of this kind are usually subject to special national rules. There are two differences between the UN Sales Convention text and the ULIS text. First, the former excludes auction sales and, second, the ULIS excludes ships, aircraft and vessels only if they are, or will be, subject to registra-

20. This rule is particularly necessary for those countries that apply commercial law rules to parties characterised as commercial parties and different rules to other parties. To some extent the non-application of the Convention and ULIS to consumer sales achieves the same purpose.

21. The relevant provisions are Art.2(b)-(f) of the UN Sales Convention and Art.5(a)-(d) of ULIS. 
tion. ${ }^{22}$ There is also a problem that what is meant by a vessel in the ULIS is not very clear, and domestic registration requirements differ greatly from country to country.

\section{Application of the Convention to International Contracts of Sale of Goods}

The UN Sales Convention, as stated in Article 1(1), applies to contracts for the sale of goods between parties whose places of business are in different States: when the States are contracting States; or when the rules of private international law lead to the application of the law of the contracting State. The fact that the parties have their places of business in different States is to be disregarded whenever this fact does not appear either from the contract or from any dealings between, or from information disclosed by, the parties at any time before or at the conclusion of the contract. ${ }^{23}$ The ULIS, as expressed in Article 1, applies to contracts for sale entered into by parties whose places of business are in the territories of different contracting States, where the contract satisfies one of three specified criteria of internationality. It will apply in the following situations:

(a) where the contract involves the sale of goods which are at the time of the conclusion of the contract in the course of carriage or will be carried from the territory of one State to the territory of another;

(b) where the acts constituting the offer and the acceptance have been effected in the territories of different States;

(c) where delivery of the goods is to be made in the territory of a State other than that within whose territory the acts constituting the offer and the acceptance have been effected. ${ }^{24}$

Thus the Uniform Laws and the Convention differ markedly in the sphere of their application. For the ULIS and the ULF to apply it is necessary that borders be crossed either in the formation or in the

22. ULIS, Art.5(b).

23. UN Sales Convention, Art.1(2).

24. There are several derogations allowed by ULIS in Arts.3 and 4. Art.4 reads that "Any State which has previously ratified or acceded to one or more Conventions on conflict of laws in respect of the International Sale of Goods may, at the time of the deposit of its instrument of ratification of or accession to the present Convention, declare by a notification addressed to the Government of the Netherlands that it will apply the Uniform Law in cases governed by one of those previous Conventions only if that Convention itself required the application of the Uniform Law", and Art.3 provides that "by Way of derogation from Article 1 of the Uniform Law, any State may, at the time of the deposit of its instrument of ratification of or accession to the present Convention declare by a notification addressed to the Government of the Netherlands that it will apply the Uniform Law only if each of the parties to the contract of sale has his place of business or, if he has no place of business, his habitual residence in the territory of a different contracting State, 
execution of the contract, or that formation and execution each take place in different countries. These requirements are not retained in the UN Sales Convention, whose application requires only that the parties' places of business be located in different States, even when formation and execution both took place in a single State. The UN Sales Convention in Article 95 permits a State to declare at the time of ratification that it will not be bound by the second criterion of applicability contained in sub-paragraph 1(b) of Article 1 of the Convention. Another important difference which may be noted in this context is that Article 5 of the ULIS, which allowed a State to adopt the Uniform Laws on the basis that the relevant State will apply them only to contracts in which the parties have chosen the Convention as the law of the contract, is not retained in the Convention. This reservation was in fact made by the United Kingdom. The UN Sales Convention applies without any positive opting in. The Convention states in Article 6 that, subject to Article 12 , it applies to contracts for the sale of goods within the sphere of application, unless the parties excluded its application in whole or in part.

Under the Uniform Laws every signatory State promises to apply the Convention to all international sales which come before its courts whether or not the parties' States are parties to the Uniform Laws, to the extent that it does not affect the application of any mandatory provision of law which would have been applicable had the parties not chosen the Uniform Law. This is without regard to the rules of private international law, which Article 2 of the ULIS states shall be excluded for the purposes of the application of the ULIS, subject to any provision to the contrary in the ULIS. The application of the Convention in this situation could lead to the application of a law which was unpredictable at the time of the conclusion of the contract. By requiring that there be a substantial relationship between an international sales transaction and a State which ratifies or accedes to it, the UN Sales Convention seems to have resolved this problem, and its approach on the subject is much more appropriate and acceptable than that of the ULIS.

\section{GENERAL PROVISIONS OF SPECIAL IMPORTANCE}

\section{A. Interpretation and Matters not Expressly Covered}

Article 7(1) of the UN Sales Convention states that in the interpretation of the Convention regard is to be had to its international character and to the need to promote uniformity in its application and the observance of good faith in international trade. The ULIS does not contain a pro-

and in consequence may insert the word 'Contracting' before the word 'States' where the latter word first occurs in paragraph 1 of Article 1 of the Uniform Law." Similar derogations are allowed by ULF, see Arts.2-4. 
vision on the interpretation of the text itself. In Article 17 it attempts to base interpretation on the general principles underlying it. Further, Article 8(1), (2) and (3) of the UN Sales Convention contains a provision on the interpretation of statements by and other conduct of a party, which will be relevant for the interpretation of the contract as distinct from the Convention. The UN Sales Convention in Article 7(1) employs the concept of good faith as mentioned above. Although courts may consider it a vague concept capable of a wide variety of interpretations, the good faith principle can serve a number of useful purposes. It gives the courts the flexibility which is needed by any code to make it work in practice. This allows tribunals to avoid over-literal interpretations which would provide inequitable results unintended by the drafters, and could prevent a too hasty resort to domestic law. Furthermore, the obligation of good faith itself may foster an atmosphere of mutual trust among businessmen. ${ }^{25}$

The Uniform Laws and the Convention differ significantly in their methods of resolving issues not expressly settled by their provisions. The ULIS states in Article 17 that questions concerning matters governed by it and which are not expressly settled therein shall be settled in conformity with the general principles on which it is based. The ULIS does not permit the application of national law to resolve such issues, unless, of course, the contract provides otherwise. The elimination of national law in the ULIS rules leaves the parties with the alternatives either to exclude the Convention or to incorporate a very large number of detailed legal rules in their contract. Courts would be unable to deduce the general principles essential to internal analogy. Further, the ULIS does not provide the courts with an explicit statement of the general principles on which it is based. The UN Sales Convention (Article 7(2)), like the ULIS, states that questions not expressly settled by the Convention are to be settled, in the first instance, in conformity with the general principles on which the Convention is based. But Article 7(2) adds that in the absence of such principles, such questions are to be settled "in conformity with the law applicable by virtue of the rules of private international law". Thus courts are to make reference to on or more systems of national law to fill gaps in the Convention.

\section{B. Usage}

The manner in which the UN Sales Convention deals with usage in international commerce differs considerably from the treatment of usage in the ULIS. Article 9(1) and (2) of the ULIS provides that the parties shall be bound by any usage which they have expressly or

25. See Commentary on Article 7, UN Conference on Contracts for the International Sale of Goods, Vienna, 10 Mar.-11 Apr. 1980, UN Official Records (1981), p.18. 
impliedly made applicable to their contract and by any practices which they have established between themselves; by usages which reasonable persons in the same situation as the parties usually consider to be applicable to their contract (in the event of conflict with the ULIS, the usages prevail unless otherwise agreed by the parties); and it provides that where expressions, provisions or forms of contract commonly used in commercial practice are employed, they shall be interpreted according to the meaning usually given to them in the trade concerned. Article 9 has been criticised ${ }^{26}$ in particular the provision that the parties shall be bound by usages which reasonable persons in the same situation usually consider to be applicable to their contract, it being argued that traders in developing countries might find themselves bound by usages of which they were unaware and in the formation of which their countries played no part. In some countries it has been thought that this provision of the ULIS could very well be against public policy.

The UN Sales Convention, in its analogous Article 9, has avoided these objections by binding the parties to any usage to which they have agreed either through their negotiations or by their course of dealing. The parties are considered, unless otherwise agreed, to have impliedly made applicable to their contract or its formation a usage of which the parties knew or ought to have known and which in international trade is widely known to, and regularly observed by, parties to contracts of the type involved in the particular trade concerned. ${ }^{27}$ The UN Sales Convention may be said to respond better than the Uniform Laws to the practical realities of trade practices.

\section{FORMATION OF THE CONTRACT}

\section{A. Form}

Article 11 of the UN Sales Convention and Article 15 of the ULIS both state in very similar terms that a contract of sale need not be concluded in or evidenced by writing and is not subject to any other requirements as to form. A contract of sale may be proved by any means, including witnesses. However, in Article 96 the UN Sales Convention allows contracting States to make a reservation on this point. It states that a contracting State whose legislation requires contracts of sale to be concluded in or evidenced by writing may at any time make a declaration in accordance with Article 12 to the effect that any provision of Article 11, Article 29, or Part II of the Convention allowing a contract

26. Idem, p.19, and see also P. Winship, "International Sales Contracts Under the 1980 Vienna Convention" (1984) 17(1) Uniform Commercial Code L.J. 55-71.

27. See P. Schlechtriem, Uniform Sales Law; the United Nations Convention on Contracts for the International Sale of Goods (1986), p.40. 
of sale or its modification or termination by agreement or any offer, acceptance, or other indication of intention to be made in any form other than in writing, shall not apply where any party has his place of business in that State. ${ }^{28}$

\section{B. Offer}

The definition of an offer is similar under both Conventions. Article 14(1) of the UN Sales Convention defines an offer as a proposal for concluding a contract, addressed to one or more specific persons, which is sufficiently definite and which indicates the intention of the offeror to be bound in case of acceptance. Under Article 4(1) of the ULIS an offer is sufficiently definite if it permits the conclusion of the contract by acceptance. The UN Sales Convention states in Article 14 that a proposal is sufficiently definite if it indicates the goods and expressly or implicitly fixes or makes provision for determining the quantity and the price. ${ }^{29}$ Article 14(2) states that a proposal other than one addressed to one or more specific persons is to be considered merely as an invitation to treat unless the contrary is clearly indicated by the person making the proposal.

\section{Revocation of an Offer}

Article 5(2) of the ULF and Article 16(1) of the UN Sales Convention contain rules regarding the revocation of an offer. The rules are for the most part the same. They both accept the general principle that an offer may be revoked at any time, but do make an offer irrevocable in certain cases. Under Article 5(2) of the ULF, an offer cannot be revoked if the revocation is not made in good faith; the offer states a fixed time for acceptance; and there is some other indication that it is irrevocable: such an indication may result from the circumstances, preliminary negotiations, practices or usages. The UN Sales Convention states in Article 16(2)(a) and (b) that an offer cannot be revoked if it indicates, by stating a fixed time for acceptance or otherwise, that it is irrevocable or if it was reasonable for the offeree to rely on its being irrevocable and he acted in reliance on it. Article 17 of the UN Sales Convention provides that an offer, even if it is irrevocable, is terminated when rejection reaches the offeror. Thus if the offer is stated to be open for a specified period of ten days, the offeror is free to deal elsewhere if he receives a

28. Art.96 was included as laws of a few countries impose strict formal requirements for the making of foreign trade contracts. See J. Honnold, op. cit. supra n.1, at p.129. See also Report of the UN Commission on International Trade Law, 4th Session, p.21, UN Commission on International Trade Law, Yearbook, Vol.II.

29. UN Sales Convention, Art.14(1), see Commentary on Article 14, UN Conference, op. cit. supra n.25, at p.20. 
rejection after three days. There is no equivalent provision in the ULF. The approach taken by the UN Sales Convention expressly puts the matter beyond doubt. ${ }^{30}$

\section{Acceptance}

An acceptance is defined in Article 18(1) of the UN Sales Convention as a statement made by, or other conduct of, the offeree which indicates assent to an offer. The corresponding provision of the ULF (Article $6(1)$ ) does not define an acceptance and merely states that an acceptance consists of a declaration communicated by any means whatsoever to the offeror. The term "declaration" seems to have an unduly formal air about it and may give the ordinary businessman the impression that he needs to perform some solemn act or execute some formal document. On the question whether silence amounts to acceptance, Article 6(2) of the ULF may be construed to provide that a term in the offer stipulating that silence shall amount to acceptance is valid. Article 18(1) of the UN Sales Convention clearly states that silence shall not in itself amount to acceptance. This indicates a general rule. Silence may amount to acceptance, if coupled with other factors giving sufficient assurance of the offeree's intention. For instance, both Article 18(3) of the UN Sales Convention and Article 6(2) of the ULF recognise that, as a result of practices established between the parties and usage, an offer can be accepted by the offeree performing an act, such as the dispatch of goods or the payment of the price.

Article 18(2) of the UN Sales Convention states that acceptance takes effect when it reaches the offeror. It is clearer than the equivalent provision in Article 6(2) of the ULF. Article 8(1) of the ULF and Article 18(2) of the UN Sales Convention provide that an acceptance will not be effective if it does not reach the offeror within the time he has set or, if no time limit is set, within a reasonable time. An oral offer must be accepted immediately unless the circumstances indicate otherwise. Where acceptance takes the form of an act, the act must be performed within the same time limits. The UN Sales Convention, however, provides clearly in Article 18(3) that such acts are effective even without notice to the offeror. It also makes it explicit that the acceptance is effective at the moment the act is performed. This removes any ambiguity which may be inherent in the corresponding provisions of the ULF, Article 5(3).

Article 8(2) of the ULF states that, in the absence of an indication to the contrary, the period for acceptance runs from the day the offeror's letter was dated and if it was contained in a telegram from the hour of

30. See Schlechtriem, loc. cit. supra n.27. 
the day the telegram was handed in. Article 20(1) of the UN Sales Convention is more explicit: the date of the letter is the date shown on it; if no date is shown, it is the date on the envelope. In the case of an offer made by instantaneous means of communications (e.g. telephone or telex), the period runs from the moment it reaches the offeree. It is further provided in Article 20(2) that if notice of acceptance cannot be delivered to the offeror because the last day of the period is an official holiday or non-business day, the period is extended to the first business day following. Article 21(1) of the UN Sales Convention has the effect that a late acceptance is not effective unless, without delay, the offeror informs the offeree that it is effective. This rule reproduces the rule in Article 9(1) of the ULF. Article 21(2) of the UN Sales Convention, corresponding to Article 9(2) of the ULF, deals with an acceptance which, though made in time, is received late because of a delay in transmission. In this case, the late acceptance is considered to be effective unless the offeror otherwise informs the offeree without delay.

The general rule in both Article 19(1) of the UN Sales Convention and Article 7(1) of the ULF is that an offeree must accept the offer as it stands: if he attempts to add or subtract anything from it, he is not accepting it but making a counter-offer. In both Article 7(2) of the ULF and Article 19(2) of the UN Sales Convention this general rule is qualified: a reply which purports to be an acceptance but contains additional or different terms which do not materially alter the terms of the offer constitute an acceptance unless the offeror, without undue delay, objects orally to the discrepancy or dispatches a notice to that effect. This is all the ULF provides on the matter. The UN Sales Convention, however, goes further in Article 19(3), where it gives examples of some of the types of changes that would amount to a material alteration in the terms of an offer. It states that additional or different terms relating, among other things, to the price, payment, quality and quantity of the goods, place and time of delivery, extent of one's party's liability to the other or the settlement of disputes are considered to alter the terms of the offer materially.

\section{RIGHTS AND DUTIES OF THE BUYER AND SELLER}

\section{A. Obligations of the Seller}

The general obligations of the seller are summed up in Article 30 of the UN Sales Convention and Article 18 of the ULIS. ${ }^{31}$ These two

31. The topics covered under Part III of the UN Sales Convention are the same as those covered under Chaps.II and III in ULIS. The way of presentation has changed. Within the chapter on obligations of the seller, the UN Sales Convention, after giving the general rule in Art.30, separates clearly into three different sections the topics of delivery of goods and 
provisions contain detailed treatment of the seller's obligations in respect of delivery of the goods and their conformity with the contract. The seller must deliver the goods, hand over any documents relating to the goods and transfer the property in the goods. The Conventions both also deal in a similar way with the following matters: place of delivery, insurance, time of delivery, handing over of documents and third party claims. Article 35(1) of the UN Sales Convention and Article 33(1)(a) of the ULIS both require the seller to deliver goods which are of the quantity, quality and description required by the contract and which are contained or packaged in the manner required by the contract. Except where otherwise agreed, the goods do not conform with the contract unless they are fit for the purpose for which goods of the same description would ordinarily be used; are fit for any particular purpose expressly or implicitly made known to the seller at the time of the conclusion of the contract, except where the circumstances show that the buyer did not rely, or that it was unreasonable for him to rely, on the seller's skill and judgment; possess the qualities of goods which the seller has held out to the buyer as a sample or model; and are contained or packaged in the manner usual for such goods or, where there is no such manner, in a way adequate to preserve and protect the goods. But the seller is not liable for any lack of conformity if at the time of the conclusion of the contract the buyer knew or could not have been unaware of such lack of conformity.

Under Article 39(1) and (2) of the ULIS and Article 39(1) of the UN Sales Convention, the buyer loses the right to rely on a lack of conformity of the goods if he does not give notice to the seller specifying the nature of the lack of conformity within a reasonable time after he has discovered it or ought to have discovered it. But this is mitigated by the saving that the buyer may still reduce the price in accordance with Article 50 of the UN Sales Convention or claim damages, except for loss of profit, if he has a reasonable excuse for his failure to give the required notice. However, the buyer loses the right to rely on a lack of conformity of the goods if he does not give the seller notice thereof at the latest within a period of two years from the date on which the goods were actually handed over to the buyer, unless this time is inconsistent with a contractual period of guarantee.

handing over of documents, the conformity of the goods and third party claims, and the remedies for breach of contract by the seller. The advantage of this structure in relation to ULIS is a clear and neat division between the obligations of the seller on one hand and the remedies of the buyer in the case of non-fulfilment of these obligations on the other. This structure is different from that of ULIS which gives the remedies in connection with the relevant obligations, e.g. as to non-performance as regards time and place, Arts.29-32; as to non-conformity, Arts.41-49; and the other obligations in Art.55. 


\section{B. Remedies for Breach of Contract by the Seller}

In the area of remedies, there are major differences between the Uniform Laws and the UN Sales Convention. In addition to the substantive differences, the UN Sales Convention provisions are more general and much less detailed. ${ }^{32}$ The buyer is granted four remedies: specific performance, avoidance, damages and reduction in price. There is a general rule under both Conventions that the buyer may obtain specific performance whenever the seller fails to perform his obligations. This is contained in Article 46(1) of the UN Sales Convention and Article 55(2) of the ULIS. The buyer loses this right if he has resorted to a remedy which is inconsistent with this requirement, such as avoidance and reduction of price. Under the ULIS this qualification is left to implication. Under both Conventions the buyer can obtain damages in addition to specific performance to compensate him for any additional loss caused by the delay in performance.

The rights of the buyer to claim substitution of defective goods and the right to declare avoidance in case of non-conformity have been restricted in the UN Sales Convention. Also, the concept of "ipso facto" avoidance has been deleted and the definition of the term "fundamental breach" has been changed. The ULIS's distinction between several types of breach and its corresponding division of remedies has been relinquished in favour of two basic contractual violations with largely uniform remedies: breach of contract by the buyer including fundamental breach, and breach of contract by the seller also including fundamental breach. The concept of delivery, which was central to the discussion of performance and the transfer of risk in the ULIS, has also been abandoned. The issues which the ULIS tended to determine in terms of delivery are governed by a descriptive definition of the seller's obligations for performance and the prerequisites for the transfer of risk. ${ }^{33}$

The UN Sales Convention provides in Article 46(2) that if the goods do not conform with the contract the buyer may require delivery of substitute goods if the lack of conformity constitutes a fundamental breach and a request for substitute goods is made either in conjunction with notice of non-conformity under Article 39 or within a reasonable time thereafter. The buyer may also require the seller under Article 46(3) to remedy the lack of conformity by repair, unless this is unreasonable having regard to all the circumstances, but a request for repair must be made either in conjunction with notice given under Article 39 or within a reasonable time thereafter. A similar provision in Article 42(c) of the

32. There are 23 articles in ULIS dealing in one way or another with remedies for failure of the seller to carry out his obligations; this is covered in the UN Sales Convention by only eight articles.

33. Schlechtriem, op. cit. supra n.27, at p.375. 
ULIS relates only to a sale of unascertained goods. This rule is rather hard on the seller: if the defect is a minor one and does not seriously prejudice the buyer, it should be enough for him to obtain damages or to reduce the price. An obligation to deliver substitute goods could create difficulties for the seller if he has none available or is unable to dispose of the goods returned. There is also a difference in the way in which the application of specific performance is restricted. The ULIS states in Article 25 that the buyer may not obtain specific performance if it is in conformity with usage and reasonably possible for the buyer to purchase substitute goods to replace those to which the contract relates. In such a case the contract is avoided as from the time when the purchase should be effected. Application of the remedy of specific performance is limited in the UN Sales Convention by Article 28, which states that a court does not have to order specific performance if it would not do so in similar cases governed by domestic law. ${ }^{34}$

The buyer may under both Article 49(1)(a) and (b) of the UN Sales Convention and Article 75 of the ULIS declare the contract avoided if the seller has committed a fundamental breach of contract or failed to deliver within a reasonable time. A fundamental breach is defined in Article 25 of the UN Sales Convention as one which "results in substantial detriment to the other party unless the party in breach did not foresee and had no reason to foresee such a result". The ULIS defines fundamental breach in Article 10 in terms of whether the seller knew, or ought to have known, that a reasonable person in the same situation as the buyer "would not have entered into the contract if he had foreseen the breach and its effects". The UN Sales Convention also omits Article 28 of the ULIS, which states that failure to deliver the goods at the date fixed is always a fundamental breach if the price of the goods is quoted on a market where the buyer can obtain them.

The Uniform Law and the UN Sales Convention have different provisions with regard to the procedure on a declaration of avoidance. Under Article 49(1) of the UN Sales Convention, when the grounds of avoidance set out in Article 49(2)(a) and (b) exist, and the buyer wishes the contract avoided, he must make a declaration of avoidance. The position under the ULIS is not quite the same. Although a declaration of avoidance is the normal way in which a contract is avoided, there are certain cases under the ULIS where avoidance takes place automatically. Articles 26(1) and 30 of the ULIS state that if the buyer has the right to avoid the contract because there is a fundamental breach and he fails to inform the seller within a reasonable time whether he intends to exercise the right or not, the contract is ipso facto avoided. Likewise, if

34. Under Art.28, rules of domestic law on specific performance can prevail over the rules of the Convention. See Honnold, op. cit. supra n.1, at p.195. 
the seller asks the buyer to make known his decision, and the buyer does not reply promptly, the contract is automatically avoided. The solution adopted in the UN Sales Convention in Article 49(2) is that the buyer loses his right to avoid the contract unless he makes his declaration within a reasonable time after he has become aware that delivery has been made in cases where the seller has delivered the goods and in respect of any other breach other than late delivery, within a reasonable time after he knew or ought to have known of the breach. This solution is more practical and sound as parties require to know and should know where they stand.

Where the goods do not conform with the contract, Article 50 of the UN Sales Convention and Article 46 of the ULIS give the buyer the right to reduce the price. ${ }^{35}$ Whether or not the price has already been paid, the buyer may reduce the price by the same proportion as the value of the delivered goods at the time of delivery bears to the value that conforming goods would have had at that time. Article 48 of the UN Sales Convention, subject to Article 49, and Article 44(1) of the ULIS allow the seller after the date for delivery a right to remedy his failure at his own expense, if he can do so without unreasonable delay and without causing the buyer unreasonable inconvenience or uncertainty of reimbursement by the seller of expenses advanced by the buyer.

\section{Obligations of the Buyer and Related Remedies}

The main obligations of the buyer under both Conventions are to pay the price and to take delivery of the goods as required by the contract and the provisions of both Conventions. The relevant provisions are Articles 53 and 55 of the UN Sales Convention and Articles 56 and 65 of the ULIS. The buyer's obligation to take delivery consists of two elements. The first is that he must do all the acts which could reasonably be expected of him in the contract or which are necessary in order to enable the seller to make delivery. The buyer's obligation is limited to this under the UN Sales Convention. He is not obliged to do all such acts as are necessary in order to enable the seller to hand over the goods, as is the case under the ULIS. The second element in both Conventions consists of taking over the goods.

The seller may under Article 64(1)(a) of the UN Sales Convention and Articles 62(2), 62, 66 and 70 of the ULIS declare the contract avoided if the failure by the buyer to perform any of his obligations amounts to a fundamental breach. The seller may fix an additional, reasonable period of time for the buyer to perform his obligations

35. See E. Bergsten and A. J. Miller, "The Remedy of Reduction of Price" (1979) 27 A.J.C.L. 255. 
(Article 63(1) of the ULIS) and, if the buyer does not within such additional period perform his obligation to pay the price or take delivery of the goods, or if he declares that he will not do so within such period, the seller may declare the contract avoided (Article 64(1)(b) of the UN Sales Convention). Under the UN Sales Convention, the contract is avoided as a result of the buyer's breach only if the seller declares the contract avoided. ${ }^{36}$ Articles 61(2) and 62(1) of the ULIS provide for ipso facto avoidance in certain situations such as where the failure to pay the price at the date fixed amounts to a fundamental breach of the contract, in which event the seller may either require the buyer to pay the price or declare the contract avoided. He shall inform the buyer of his decision within a reasonable time, otherwise the contract shall be ipso facto avoided. This solution appears to provide less certainty than that of the UN Sales Convention.

\section{GENERAL PROVISIONS ON RIGHTS AND DUTIES OF PARTIES}

\section{A. Passing of Risk}

The passing of risk is dealt with in Article 66 of the UN Sales Convention and Article 97 of the ULIS. The two Conventions differ significantly in their treatment of this subject. ${ }^{37}$ The UN Sales Convention attaches consequences to a fact while the ULIS uses the conformity of goods as the basis. Article 97(1) of the ULIS provides that risk passes upon delivery, which in general consists in handing over to the buyer, or to a third party such as a carrier, or transfer to the buyer, of conforming goods. The general principle in the UN Sales Convention is that risk passes when goods are taken over by the buyer. This principle has much to commend it. In modern times it largely boils down to the question of who should insure and it is more logical that at any point in time the party in possession who has the care of the goods and is best able to assess the risk of loss or damage and to do something about it should bear the risk. The UN Sales Convention, in line with its concept of the passing of risk, provides a description of the prerequisite of the passing of risk. Article $67(1)$ provides that in the case of contracts of sale which involve carriage of goods, if the seller is not bound to hand them over at a particular place the risk passes to the buyer when the goods are handed over to the first carrier for transmission to the buyer in accordance with the contract of sale. If the seller is bound to hand the goods over to a carrier at a particular place, the risk does not pass until the

36. United Nations Conference, op. cit. supra n.25, at p.54, and see UN Sales Convention, Art.64(1)(d).

37. For a detailed discussion of this subject see Schlechtriem, op. cit. supra n.27, at p.86, and Roth, "The Passing of Risk" (1979) 27 A.J.C.L. 291-310. 
goods are handed over to the carrier at that place. But the risk does not pass to the buyer until the goods are clearly identified to the contract (Article 67(2)). In respect of goods sold in transit, the risk passes to the buyer from the time of the conclusion of the contract (Article 68). This is qualified in the same article by the provision that if the circumstances so indicate the risk is assumed by the buyer from the time the goods were handed over to the carrier who issued the documents embodying the contract of carriage. There is no equivalent provision in the ULIS.

There is an exception in cases where at the time of the conclusion of the contract the seller knew or ought to have known that the goods had been lost or damaged and did not disclose this to the buyer. Under the UN Sales Convention, such loss or damage is at the risk of the seller unless he discloses it to the buyer. Article 99(2) of the ULIS provides that the risk remains with the seller until the time of conclusion of the contract. The ULIS does not make clear that the risk passes to the buyer if he was informed of the loss or damage and, second, under the UN Sales Convention the seller is liable only for that loss or damage of which he knew or ought to have known. This is not necessarily the case under the ULIS. In all other cases the UN Sales Convention provides that the risk passes to the buyer when he takes over the goods or, if he does not do so in due time, from the time when the goods are placed at his disposal, and he commits a breach of contract by failing to take delivery (Article 69). If the contract relates to goods not then identified, the goods are not considered to be placed at the disposal of the buyer until they are clearly identified to the contract. If the seller has committed a fundamental breach, the articles on risk do not impair the remedies available to the buyer on account of the breach.

\section{B. Provisions Common to the Obligations of the Seller and the Buyer}

\section{Suspension of obligations}

Certain provisions are common to both the seller and the buyer. Article 73(1) of the ULIS and Article 71(1)(a) and (b) of the UN Sales Convention provide that a party may suspend the performance of his obligations. Under the UN Sales Convention, he may do so if, after the conclusion of the contract, it becomes apparent that the other party will not perform a substantial part of his obligations as a result of either a serious deficiency in his ability to perform or in his creditworthiness, or his conduct in preparing to perform or in performing the contract. The ULIS provision gives the economic ground as the only ground for suspension. Article 71(3) of the UN Sales Convention states that a party who suspends performance must immediately give notice of the suspension to the other party and must continue with performance if the other 
party provides adequate assurance of his performance. The ULIS does not state what happens after one party exercises his right to suspend performance of his obligations.

\section{Damages}

Article 82 of the ULIS and Article 74 of the UN Sales Convention deal with the calculation of damages. Both articles define damages as a sum equal to the loss, including loss of profit, suffered by a party in consequence of the breach. Such damages may not exceed the loss which the party in breach foresaw or ought to have foreseen at the time of the conclusion of the contract, in the light of the facts and matters of which he then knew, or ought to have known, as a possible consequence of the breach of the contract. There is a difference between the wording of the UN Sales Convention provision and that of the ULIS in that the ULIS provision does not use the term "foresaw". This could be interpreted to mean that under the UN Sales Convention the foreseeability test is both subjective and objective while under the ULIS it is objective only. In both cases, all the circumstances of a case must be taken into account. Both Article 83 of the ULIS and Article 78 of the UN Sales Convention provide that where the breach consists of delay in payment of the price, the seller is entitled to interest without prejudice to any claim for damages. ${ }^{38}$

Where the contract is avoided and a substitute transaction is carried out, Article 75 of the UN Sales Convention and Article 85 of the ULIS state that the party claiming damages may obtain the difference between the contract price and the price under the substitute transaction and any further damages recoverable under the general principle. If there is no substitute transaction, Article 76(1) of the UN Sales Convention lays down the rule that the damages will be equal to the difference between the contract price and the current price at the time when the party obtaining damages first had the right to declare the contract avoided. The provision in the ULIS (Article 84(1)) is similar, except that the relevant date is when the contract was actually avoided. In Article 76(2) the UN Sales Convention defines current price as the price prevailing at the place where delivery of the goods should have been made or, if there was no current price at that place, the price at another place which serves as a reasonable substitute, making the allowance for differences in the cost of transporting the goods. Article 84 of the ULIS has a similar provision except that it takes the price in the market in which the transaction took place as the basis of calculation.

Article 77 of the UN Sales Convention and Article 88 of the ULIS both impose a duty to mitigate the damage and, if the innocent party

38. See also Honnold, op. cit. supra n.1, at p.415. 
fails to take such measures, the party in breach may claim a reduction in the damages of the amount by which the loss should have been mitigated.

\section{Exemptions}

Article 79(1) of the UN Sales Convention and Article 74 of the ULIS are concerned with the question of when a party may be exempted from liability for failure to perform any of his obligations if he is unable to perform due to circumstances beyond his control. Under both Conventions, a party is not liable for a failure to perform any of his obligations if he proves that the failure was due to any impediment beyond his control and that he could not reasonably be expected to have taken the impediment into account at the time of the conclusion of the contract or to have avoided or overcome it or its consequences. Article 79(2) of the UN Sales Convention states that if the failure to perform is due to the failure of a third person whom he engaged to perform the whole or a part of the contract, the defaulting party is exempt from liability only if two conditions are fulfilled: first, he must himself be exempt under the conditions mentioned above and, second, the third person must also be so exempt. This provision has no counterpart in the ULIS.

Article 79(3) of the UN Sales Convention provides that the exemption applies only for the period during which the impediment exists. Article 74(2) of the ULIS, on the other hand, states that even if the impediment is only temporary, the party will be permanently relieved of his obligation if, by reason of the delay, performance would be so radically changed as to amount to a quite different obligation from that contemplated by the contract. In such a case, under the UN Sales Convention it would seem the party would be obliged to perform. By Article 79(4) the UN Sales Convention requires the party who fails to perform to give notice to the other party of the impediment and its effect. If the notice is not received within a reasonable time after the party in default knew, or ought to have known, of the impediment, he is liable for damages resulting from such non-receipt. This provision has no equivalent in the ULIS. Article 79(5) of the UN Sales Convention states that nothing in Article 79 prevents either party from exercising any right other than to claim damages under the Convention. Article 74(3) of the ULIS, on the other hand, states that the relief provided by Article 74 shall not exclude the avoidance of the contract under some other provision of the ULIS or deprive the other party of any right which he has under the ULIS to reduce the price, unless the circumstances which entitled the first party to relief were caused by the act of the other party or of some person for whose conduct he was responsible. This could mean that the party may not be sued for specific performance 
under the ULIS, but could be sued under the UN Sales Convention, except in cases in which national law prevents such a suit against the party.

\section{Effects of avoidance}

It is provided by both Article 78(1) of the ULIS and Article 81(1) of the UN Sales Convention that avoidance of the contract releases the parties from their obligations under it, subject to any damages which may be due. The UN Sales Convention states in Article 81(1) that avoidance does not affect any provisions of the contract for the settling of disputes or governing the respective rights and obligations of the parties consequent upon the avoidance of the contract. ${ }^{39}$ There is no similar provision in the ULIS. Article 78(2) of the ULIS and Article 81(2) of the UN Sales Convention state that if a party has performed the contract, either wholly or in part, he may claim restitution of what he has supplied or paid; if both parties are bound to make restitution, they must do so concurrently.

Under Article 79(1) of the ULIS and Article 82(1) and (2) of the UN Sales Convention, where it is impossible for the buyer to make restitution of the goods in the condition in which he received them he loses the right to declare the contract avoided. This does not apply if:

(a) the impossibility of making restitution of the goods or of making restitution of the goods substantially in the condition in which the buyer received them is not due to his act or omission;

(b) the goods or part of the goods have perished or deteriorated as a result of the examination provided for in Article 38 in the case of the UN Sales Convention; or

(c) the goods or part of the goods have been sold in the normal course of business or have been consumed or transformed by the buyer in their normal use before he discovered or ought to have discovered the lack of conformity.

The Uniform Laws and the UN Sales Convention are similar on this point, except that in Article 79 the ULIS does not give the buyer a chance to require the seller to deliver substitute goods, while Article $82(1)$ of the UN Sales Convention does. There are a number of exceptions to the rule in Article 79 of the ULIS and Article 82(1)(b) of the UN Sales Convention. For example, even if the buyer has the right to avoid the contract because he cannot make restitution, and does not

39. Schlechtriem, op. cit. supra n.27, at p.95 for more discussion of the issue. 
come within any of the exceptions, he may still claim any other remedy such as damages, specific performance or a reduction in the price. This is provided for in Article 80 of the ULIS and Article 83 of the UN Sales Convention. When restitution is made, Article 84(1), (2)(a) and (b) of the UN Sales Convention and Article 81(1) and (2) of the ULIS provide that the party must return what he has received and must also account to the other party for the benefits.

\section{Preservation of the goods}

The provisions in both the Uniform Laws and the UN Sales Convention on the question of preservation of goods are similar. Article 91 of the ULIS and Article 85 of the UN Sales Convention provide that if the buyer is in delay in taking delivery of the goods and the seller is in possession of them or otherwise able to control their disposition, the seller must take such steps as are reasonable in the circumstances to preserve them. The seller is, however, entitled to be reimbursed for any reasonable expenses resulting from steps taken to preserve the goods and he has the right to keep the goods until he is reimbursed. Similar provisions apply under Article 92(1) of the ULIS and Article 86(1) of the UN Sales Convention where the goods have been received by the buyer but he intends to reject them. If the goods have been dispatched to the buyer and placed at his disposal, but he intends to reject them, it is provided by Article 92(2) of the ULIS and Article 86(2) of the UN Sales Convention that he must take possession of them on behalf of the seller, provided that he can do so without unreasonable inconvenience and expense. This does not apply where the seller is present at the destination.

A party who is under an obligation to take steps to preserve the goods may by the authority of Article 93 of the ULIS and Article 87 of the UN Sales Convention deposit them in a warehouse of a third person at the expense of the other party provided that the expense incurred is not unreasonable. Under Article 94(1) of the ULIS and Article 88(1) of the UN Sales Convention, a party who has an obligation to preserve the goods may sell them where there has been an unreasonable delay by the party in paying the cost of preservation. The other party must first give notice of the intention to sell. There is an obligation to resell under Article 95 of the ULIS and Article 88(2) of the UN Sales Convention where the goods are subject to loss or rapid deterioration and where their preservation would involve unreasonable expense. Both Article 94(2) of the ULIS and Article 88(3) of the UN Sales Convention allow the party selling the goods to retain out of the proceeds of the sale an amount equal to the reasonable expenses of preserving and selling them, but he must account to the other party for the balance. 


\section{CONCLUSION}

THE UN Sales Convention is an improvement over its predecessor, the ULIS and the ULF. This is in fact hardly surprising in that the UN Sales Convention took the ULIS and the ULF as its starting point and improved upon them with the intention of creating an international sales law acceptable to as many countries as possible. This was made possible by the participation of the many countries that took part in drawing up the Convention. There are a number of instances in which the UN Sales Convention is preferable to the Uniform Laws. ${ }^{40}$ Reference may be made to the provision on usage, concept of consumer sales, fundamental breach, suspension of performance, avoidance, exclusion of conflict rules, passing of risk, the right of the seller to cure defects and the interpretation and gap-filling provisions. In addition there are a number of articles of the UN Sales Convention which have been tailored according to the special needs of international trade. It encourages the parties to preserve the contract and in several provisions encourages the parties to rely on less drastic means than litigation to resolve disputes. It requires parties to give prompt notice of non-conformity in goods or of a third party claim on goods. It requires parties to preserve goods in their possession. A party can under the UN Sales Convention suspend his performance of a contract if the other party at any time appears to be unable to perform and cannot on request provide adequate assurance of his ability to perform. The UN Sales Convention uses non-conceptual language comprehensible to both traders and lawyers. For instance, it avoids the terms délivrance and ipso facto which are found in the Uniform Laws.

There is a great need for a universally acceptable convention containing uniform regulations for the conclusion and fulfilment of contracts for the international sale of goods. This would generally make it possible for the existing significant discrepancies in national legislations to be removed. This would in turn promote, facilitate and reduce the cost of business transactions, if only because it will largely be unnecessary to study foreign legislation and its practices, which in any event are often inadequate as they are designed to regulate the domestic sale of goods. The existence of a widely accepted international convention on international sales contracts will eliminate a number of problems that cur-

40. Reviews of the Convention have been generally very positive, e.g. Honnold, op. cit. supra n. 1; F. Vergne, "The 'Battle of the Forms' under the 1980 United Nations Convention on Contracts for the International Sale of Goods (1985) 33 A.J.C.L. 233; G. A. Barton, "The United Nations Convention on Contracts for the International Sale of Goods XVIII" (1985); Comp. and Int. L.J. of Southern Africa 21; J. Barrignan Marcantonio, "Unifying the Law of Impossibility" (1984) 8 Hastings I.C.L. Rev. 41; L. Réczei, "The Field of Application and the Rules of Interpretation of ULIS and UNCITRAL Conventions" (1982) Acta Juridica Academiae Scientiarum Hungaricae, Tomus 157; and Winship, op. cit. supra n.26. 
rently plague international sales contracts. There is the problem of the unpredictability of the applicable law governing an international sale of goods. The parties cannot always be certain which law will apply. If the parties are from different countries, and therefore accustomed to different legal systems, the governing law will be unfamiliar to one of the parties. This in turn may make parties less inclined to enter into international transactions. National legislation is not uniform and the present law governing international transactions is not widely accepted in the world. An additional problem exists in relation to the law of certain developing countries. In some countries the law of contract has not been modernised due to lack of expertise and resources. It may be difficult to find legal rules governing particular aspects of sales transactions. In such cases there may well be advantages in having the transaction governed by the internationally accepted rules.

The UN Sales Convention received extensive worldwide participation both in its formulation and at the diplomatic meeting to consider its approval, unlike its predecessor. This is an added advantage in its quest for acceptance, especially among the many countries that were indifferent to the Uniform Laws on the political factor of non-representation. Already the diversity of the list of the States that are now parties to the UN Sales Convention indicates worldwide acceptance. The list includes Argentina, Australia, Austria, China, Egypt, Finland, France, Hungary, Italy, Lesotho, Mexico, Norway, Syria, Sweden, the United States, Yugoslavia and Zambia. They represent diverse geographical, legal, economic, political and social systems. It is suggested therefore that the UN Sales Convention has a very good chance of acceptability and of unifying the law relating to international sale of goods on a worldwide basis and thereby contributing to universal economic co-operation among States. 